\title{
Cortisol Responsiveness to Insulin-induced Hypoglycemia in Cushing's Syndrome with Huge Nodular Adrenocortical Hyperplasia
}

\author{
Kozo HASHIMOTO, Yoshiro KAWADA, Kazuharu MURAKAMI, \\ TERUHIKo HATTORI, SHuso SUEMARU, JINGo KAGEYAMA, \\ Zensuke OTA, Shunzi HAYATA*, Teruhisa OHASHI* \\ AND HIROYUKI OMORI*
}

Third Department of Internal Medicine and Department of Urology*, Okayama University Medical School, Okayama 700

\begin{abstract}
A 51-yr-old male patient with a $3 \mathrm{yr}$ history of Cushing's syndrome is described. The baseline plasma cortisol level was elevated, while the plasma ACTH levels remained at an undetectable level. Dynamic testing of pituitaryadrenal function revealed no suppression after $8 \mathrm{mg}$ of dexamethasone, and there was no response to metyrapone or CRF, while plasma cortisol showed a hyperresponse to synthetic ACTH. Plasma cortisol responded to insulininduced hypoglycemia without an obvious ACTH response. These and the computerized tomography data suggested a "huge" bilateral nodular adrenocortical hyperplasia which was later confirmed by surgery. The left and right adrenal glands weighed 55 and $76 \mathrm{~g}$, respectively. In vitro experiments, using the adrenal tissue, showed that there was an adrenal cortisol response to 1-39 ACTH but not to regular insulin, arginine vasopressin, angiotensin II, norepinephrine or epinephrine. These results indicate that plasma cortisol responded to a slight hypoglycemia-induced plasma ACTH change which was not detected in the ACTH radioimmunoassay or to factors other than ACTH which might be induced by hypoglycemia.
\end{abstract}

Bilateral adrenocortrical hyperplasia is present in approximately $70-80 \%$ of Cushing's syndrome cases (Crapo, 1979; Neville and Mackay, 1976). Bilateral "adenomatous" or nodular hyperplasia accounts for $15-20 \%$ of all cases of adrenocortical hyperplasia (Neville and Symington, 1967). Diffuse bilateral hyperplasia and micronodular hyperplasia are ACTH dependent and known as

Received January 6, 1986
Cushing's disease. Macroscopic nodules are also the causes of Cushing's syndrome. The term macronodular adrenal hyperplasia is used to describe the presence of one or more macroscopically visible nodules up to $2.0-3.0 \mathrm{~cm}$ in diameter (Neville and Mackay, 1976). When these nodules are very large, the term huge nodular adrenal hyperplasia is used. Only several cases (Kirshner et al., 1964; Hidai et al., 1975; Ishihara et al., 1977; Krivitzky et al., 1980; Murayama et 
al., 1983; Miura et al., 1984) of huge bilateral nodular adrenocortical hyperplasia with an adrenal weight over $90 \mathrm{~g}$ have been reported. The pathogenesis of this nodular adrenocortical disorder is still unknown. Some authors (Cohen, 1966; Aron et al., 1981) have proposed a primary pituitary origin and others (Meador et al., 1967; Ruder et al., 1974) a primary adrenal origin, and still others (Tucci et al., 1965; Choi et al., 1970; Smals et al., 1984) dual control with predominance by the pituitary at one time and the adrenal at another.

This paper reports on a case of huge nodular adrenocortical hyperplasia with a plasma cortisol response to insulin-induced hypoglycemia without an obvious plasma ACTH response.

\section{Case Report}

A 51-yr-old male with a 3 yr history of truncal obesity, proxismal muscle weakness and wasting, hypertension and decreased libido was admitted to our hospital in July, 1984. His medical history revealed a gastric ulcer at $31 \mathrm{yr}$ of age and urinary stones at $48 \mathrm{yr}$. The patient's mother died of cerebral apoplexy. The patient had a moon face, buffalo hump, gynecomastia, bruising, muscle atrophy, and pretibial edema. There was no obvious hirsutism, acne or striae cutis distensae. His body height was 164.5 $\mathrm{cm}$ and body weight $64 \mathrm{~kg}$. Blood pressure was $190 / 110 \mathrm{mmHg}$.

Laboratory investigations revealed a red blood cell count of $430 \times 10^{4} / \mathrm{mm}^{3}$, hemoglobin, $14.0 \mathrm{~g} / \mathrm{dl}$; hematocrit, $41.9 \%$. The white blood cell count was $9300 / \mathrm{mm}^{3}$, and platelet count, $188000 / \mathrm{mm}^{3}$. ESR was $3 \mathrm{~mm} /$ hr. Serum electrolytes were: Na, $142 \mathrm{mEq} /$ 1 ; $\mathrm{K}, 2.8 \mathrm{mEq} / \mathrm{l} ; \mathrm{Cl}, 106 \mathrm{mEq} / 1$; and $\mathrm{Ca}$ $8.4 \mathrm{mg} / \mathrm{dl}$. Serum BUN was $14.9 \mathrm{mg} / \mathrm{dl}$; creatinine, $0.64 \mathrm{mg} / \mathrm{dl}$, uric acid, $11.0 \mathrm{mg} /$ dl. Total serum protein was $6.03 \mathrm{~g} / \mathrm{dl}$; albumin $3.97 \mathrm{~g} / \mathrm{dl}$; globulin, $2.06 \mathrm{~g} / \mathrm{dl}$; GOT $9.0 \mathrm{IU}$; GPT, $12.0 \mathrm{IU}$; LDH, $476 \mathrm{IU}$; CPK, $18 \mathrm{IU}$; $\gamma$-GTP, 10 IU. 75 GTT : blood glucose levels were 142, 219, 206, 167 and $187 \mathrm{mg} / \mathrm{dl}$ at $0,30,60,90$ and $120 \mathrm{~min}$, respectively.

\section{Endocrinological investigations}

The basal hormone levels are shown in Table 1 and Figures 1-3. ACTH levels

Table 1. Baseline endocrine data on the patient.

\begin{tabular}{lcc}
\hline \multicolumn{1}{c}{ Examination } & Result & Normal range \\
\hline Urinary 17-OHCS $(\mathrm{mg} / \mathrm{day})$ & $20.7-23.6$ & $3-9$ \\
Urinary 17-KS $(\mathrm{mg} / \mathrm{day})$ & $2.4-3.2$ & $3-9$ \\
Plasma cortisol $(\mu \mathrm{g} / \mathrm{dl})$ & $19.5-26.9$ & $5.4-22.6$ \\
Plasma aldosterone $(\mathrm{pg} / \mathrm{ml})$ & 96.1 & $47-131$ \\
Plasma DOC $(\mathrm{pg} / \mathrm{ml})$ & 280.0 & $20-200$ \\
Plasma corticosterone $(\mathrm{ng} / \mathrm{ml})$ & 7.16 & $1-10$ \\
Plasma DHEA-S $(\mathrm{ng} / \mathrm{ml})$ & 249.0 & $400-1500$ \\
Plasma testosterone $(\mathrm{ng} / \mathrm{ml})$ & 1.5 & $4.0-14.5$ \\
Plasma ACTH $(\mathrm{pg} / \mathrm{ml})$ & 10 & $10-80$ \\
Plasma renin activity $(\mathrm{ng} / \mathrm{ml} / \mathrm{hr})$ & 1.73 & $0.5-2.5$ \\
Plasma norepinephrine $(\mathrm{pg} / \mathrm{ml})$ & 310.0 & $50-400$ \\
Plasma epinephrine $(\mathrm{pg} / \mathrm{ml})$ & 10.0 & 10 \\
Urinary norepinephrine $(\mu \mathrm{g} / \mathrm{day})$ & 676.0 & 90 \\
Urinary epinephrine $(\mu \mathrm{g} / \mathrm{day})$ & 7.3 & 10 \\
Urinary dopamine $(\mu \mathrm{g} / \mathrm{day})$ & 6300.0 & 700 \\
Urinary VMA $(\mathrm{mg} / \mathrm{day})$ & 4.1 & $3-8$ \\
\hline
\end{tabular}



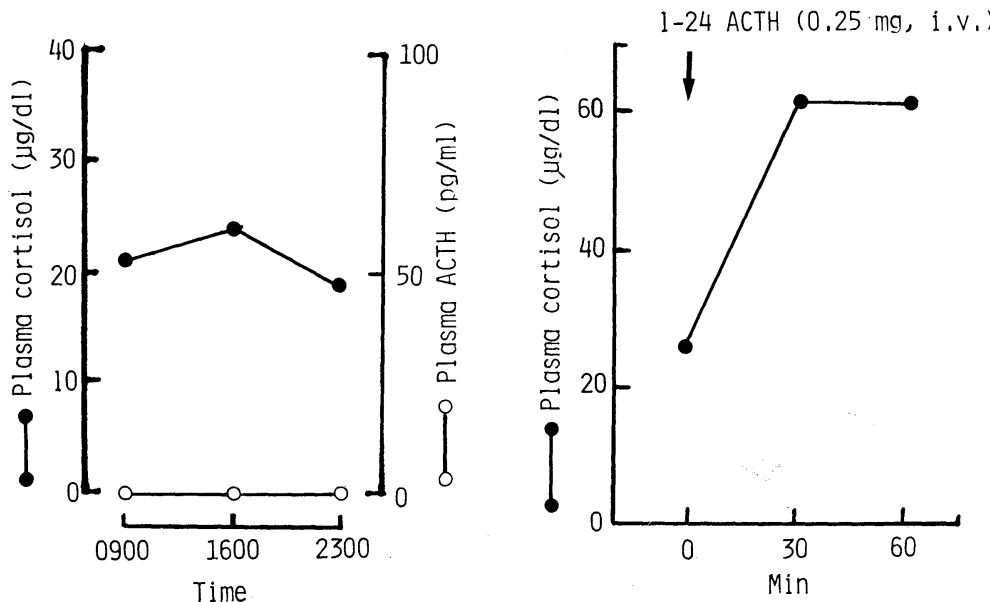

Fig. 1. Diurnal plasma cortisol rhythm and effect of iv administration of 1-24 ACTH $(0.25 \mathrm{mg})$ on the cortisol level.
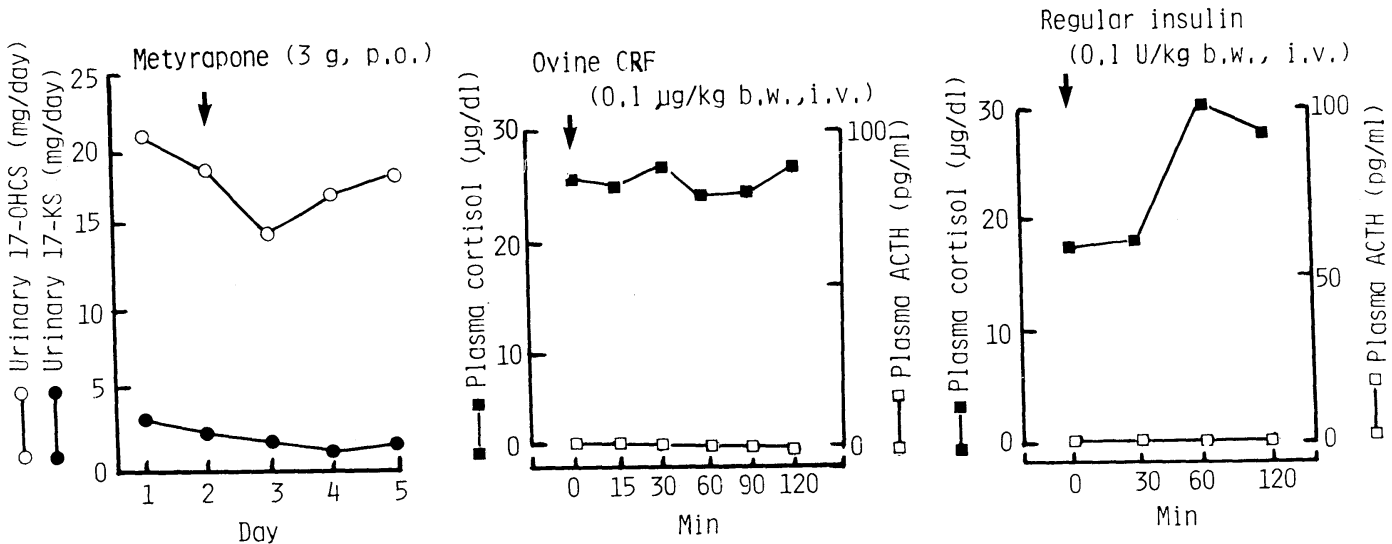

Fig. 2. Provocative tests of pituitary-adrenal function on the patient. Metyrapone $(0.5 \mathrm{~g})$ was given orally every $4 \mathrm{hr}$ for 6 times (total $3 \mathrm{~g})$. Ovine CRF $(1 \mu \mathrm{g} / \mathrm{kg})$ or regular insulin $(0.1$ $\mathrm{U} / \mathrm{kg}$ ) was given iv.

were always at undetectable levels. Plasma cortisol and urinary 17-OHCS were elevated, while urinary $17-\mathrm{KS}$ levels were near the lower limits of the normal range. Urinary norepinephrine and dopamine were elevated. Plasma ACTH and cortisol levels did not show a diurnal rhythm. Plasma cortisol responded markedly to an iv administration

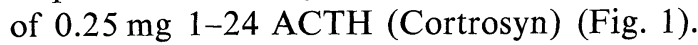
Low and high dose dexamethasone tests (2 $\mathrm{mg}$ and $8 \mathrm{mg}$ ) failed to suppress the urinary 17-OHCS and 17-KS levels. Metyrapone ( $500 \mathrm{mg}$ every $4 \mathrm{hr}$ for $24 \mathrm{hr}$, total $3 \mathrm{~g}$ ) pro- duced a reduction in urinary 17-OHCS (Fig. 2). Plasma ACTH and cortisol did not show a response to an iv administration of ovine CRF $(1 \mu \mathrm{g} / \mathrm{kg})$. In the insulin tolerance test (regular insulin, $0.1 \mathrm{U} / \mathrm{kg}$, iv) the blood glucose level dropped from $96 \mathrm{mg} / \mathrm{dl}$ to $33 \mathrm{mg} / \mathrm{dl}$ at $30 \mathrm{~min}$. Plasma ACTH stayed at undetectable level, while plasma cortisol responded normally to insulin-induced hypoglycemia. The basal levels of serum $\mathrm{GH}$, LH, FSH, PRL, TSH, T $, \mathrm{T}_{3}, \mathrm{~T}_{3}$-RSU were within the normal range. Serum GH showed no response to insulin-induced hypoglycemia. 


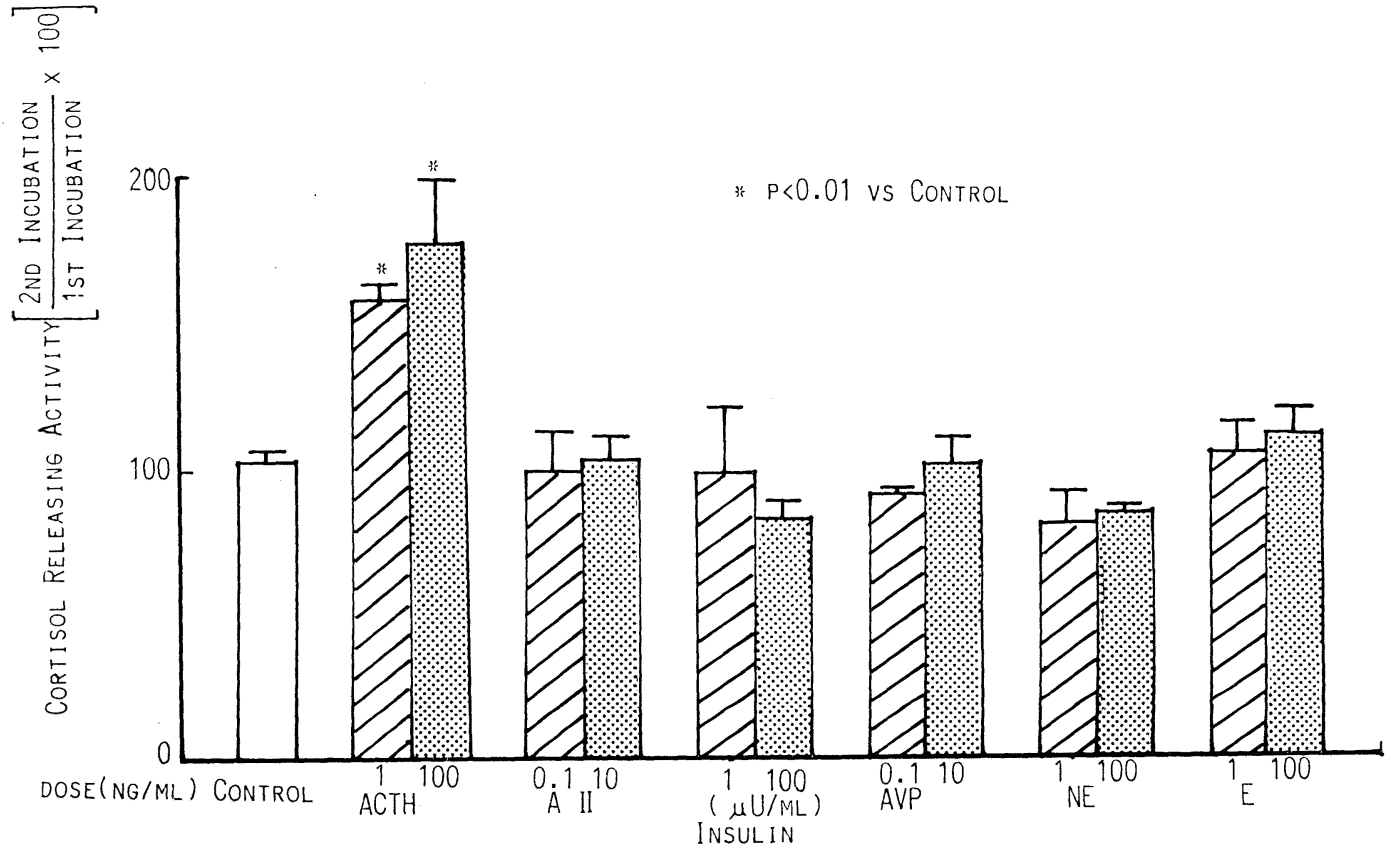

Fig. 3. Effect of 1-39 ACTH, angiotensin II (A II), insulin, arginine vasopressin (AVP), norepinephrine (NE) and epinephrine (E) on cortisol release by nodular adrenocortical tissue. Sample tissue was obtained at surgical resection. Cortisol releasing activity is the ratio of cortisol released in the second incubation medium to that released in the first incubation medium expressed as a percentage.

In the LH-RH and TRH test, serum LH, FSH and prolactin showed normal responses, whereas serum TSH showed no response. Plasma ACTH and cortisol, and serum GH, LH, FSH, PRL and TRH were measured with commercially available radioimmunoassay kits.

Adrenocortical scintiscan using ${ }^{131}$ I-adosterol revealed a large bilateral uptake of the tracer with a higher concentration in the right side. Adrenomedullary scintiscan using ${ }^{131} \mathrm{I}-\mathrm{m}$-iodobenzylguanidine (MIBG) showed accumulations of the tracer on the right side. Computerized tomography showed an enlarged multinodular mass bilaterally in the adrenal glands. Selective venous sampling revealed cortisol elevations in both adrenal veins and a marked norepinephrine elevation in the right adrenal vein (Table 2).

Table 2. Plasma cortisol and norepinephrine levels in various sites of venous catheterization.

\begin{tabular}{lcc}
\hline Vessel sampled & Cortisol $(\mu \mathrm{g} / \mathrm{dl})$ & Norepinephrine $(\mathrm{pg} / \mathrm{ml})$ \\
\hline Inferior vena cava & 17.5 & 310 \\
(below the renal vessels) & & \\
Right renal vein & 18.7 & 260 \\
Right adrenal vein & 74.0 & 1300 \\
Left renal vein & 16.0 & 340 \\
Left adrenal vein & 56.0 & 460 \\
\hline
\end{tabular}


Blood pressure did not show a positive response to glucagon, metoclopramide or phentolamine.

\section{Surgical and morphological findings}

These findings led us to suspect a huge bilateral nodular adrenocortical hyperplasia possibly with right adrenomedullary hyperplasia. Total bilateral adrenalectomy was performed in July 1984. Both halves of the adrenal glands showed huge multiple nodules ranging in size from 0.5 to $4.0 \mathrm{~cm}$. The cut surface of the nodules was yellowish in color. The left and right adrenal glands weighed 76 and $54 \mathrm{~g}$, respectively. Microscopic examination showed that the nodules were not encapsulated and were composed mainly of clear cells and partly of compact cells. The surrounding areas showed normal or compressed cortical cells. There was no evidence of malignancy. Pheochromocytoma was not found, and the existence of a right adrenomedullary hyperplasia was not confirmed because of a failure in staining.

\section{In vitro experiments}

The plasma cortisol response to insulininduced hypoglycemia without an obvious ACTH response led us to speculate that cortisol responded to insulin or an unknown substance elevated in blood by the insulininduced hypoglycemia. To test this concept, in vitro experiments were conducted. The adrenal tissue obtained at surgery was cut into small fragments which were preincubated twice (each for $30 \mathrm{~min}$ ) with Krebs Ringer bicarbonate buffer containing $0.25 \%$ bovine serum albumin and $0.2 \%$ glucose (KRBG). Then they were incubated with KRBG for $30 \mathrm{~min}$ (first incubation), followed by the second incubation for 30 min with regular insulin, 1-39 ACTH, angiotensin II (AII), arginine vasopressin (AVP), norepinephrine and epinephrine. The responses to these substances were expressed by the ratio of cortisol secretion in the second incubation medium to that in the first incubation medium. Medium cortisol was measured with a commercially available cortisol radioimmunoassay kit (Daiichi Radioisotope Ltd.). Cortisol responded well to ACTH but not to other substances (Fig. 3).

\section{Clinical course}

After the operation the patient was treated with hydrocortisone. One year after surgery, when the signs and symptoms of Cushing's syndrome had regressed, the plasma ACTH level at $0900 \mathrm{hr}$ was $123 \mathrm{pg} / \mathrm{ml}$. Six months after surgery he suffered from subacute thyroiditis but recovered following prednisolone administration.

\section{Discussion}

We present a case of Cushing's syndrome in which the preoperative investigations suggested a non-ACTH dependent Cushing's syndrome, while computerized tomography and adrenocortical scintigram suggested a huge nodular adrenocortical hyperplasia. The latter was confirmed in surgery.

Adrenocortical nodules have been classified into micro-, macro- and huge nodules depending on their size or weight. Micro nodules are $0.1-0.5 \mathrm{~cm}$ in diameter, macro nodules are up to $2.0-3.0 \mathrm{~cm}$ and huge nodules are over $90 \mathrm{~g}$ or $100 \mathrm{~g}$ in weight (both adrenal glands). The pathogenesis of nodular adrenocortical diseases is not known. Some have suggested that it is fundamentally pituitary-dependent because of the non suppressed ACTH level (Choi et al., 1970; May et al., 1983), the high ACTH levels after adrenalectomy (Hidai et al., 1975; Choi et al., 1970), and coexistence of pituitary adenoma (Schteingart and Tsao, 1980; Furukawa et al., 1981) in some patients. Smals et al. (1984) systemically compared the biochemical and pathological features of 13 patients with macronodular adrenocortical hyperplasia and 18 patients with 
diffuse adrenocortical hyperplasia (which included 9 patients with micronodular adrenocortical hyperplasia), and they suggested that macronodular adrenocortical hyperplasia might be a result of long standing Cushing's disease with varying degrees of pituitary dependence and adrenocortical autonomy. Thus, it is possible that nodular adrenocortical hyperplasia results from an initial hypersecretion of ACTH that ultimately produces semi-autonomous or autonomous nodules (tertiary nodular hyperplasia). Others have suggested that it is primarily an adrenal disorder because the plasma ACTH level cannot be stimulated with metyrapone and lysine vasopressin before adrenalectomy, and in some cases of multiple adrenocortical micronodules, adjacent areas of the adrenal gland were atrophic with lymphocytic infiltrations (Meador et al., 1967; Ruder et al., 1974; Matsukura et al., 1982; Takai et al., 1983). Meador used the term "primary adrenocortical nodular dysplasia" to refer to these cases. Ruder et al. (1974) reported that low plasma ACTH levels (7/8), no suppression of dexamethasone (10/10) and no response to metyrapone (6/6) were common abnormalities in these cases and a response to ACTH was absent in $7 / 12$ cases. Therefore, the pathogenesis of micronodular adrenocortical dysplasia may be different from micronodular adrenal hyperplasia (Nishisato et al., 1979; May et al., 1983 ; Smals et al., 1984) which becomes macronodular adrenocortical hyperplasia after a long period.

Reported cases of macronodular adrenocortical hyperplasia whose pituitary adrenocortical functions were reported (27 cases) (Mellinger \& Smith, 1956; Mosier et al., 1960 ; Silverman et al., 1963; Tucci et al.,

Table 3. Reported cases of huge nodular adrenocortical hyperplasia.

\begin{tabular}{|c|c|c|c|c|c|c|c|}
\hline & $\begin{array}{l}\text { Kirschner } \\
1964\end{array}$ & $\begin{array}{l}\text { Hidai } \\
1975\end{array}$ & $\begin{array}{c}\text { Ishihara } \\
1977\end{array}$ & $\begin{array}{l}\text { Krivitzky } \\
1980\end{array}$ & $\begin{array}{l}\text { Murayama } \\
1983\end{array}$ & $\begin{array}{l}\text { Miura } \\
1984\end{array}$ & $\begin{array}{l}\text { Our } \\
\text { case }\end{array}$ \\
\hline Sex & $\mathrm{F}$ & $\mathbf{M}$ & $\mathbf{M}$ & $\mathrm{F}$ & $\mathrm{F}$ & $\mathrm{F}$ & $\mathbf{M}$ \\
\hline Age & 40 & 47 & 51 & 39 & 49 & 62 & 51 \\
\hline $\begin{array}{l}\text { Duration of disease (yrs) } \\
\text { Adrenal weight }(\mathrm{g})\end{array}$ & 9 & 2 & 4 & & 9 & & 3 \\
\hline left/right & $44 / 50$ & $105 / 56$ & $141 / 85$ & $30 / 80$ & $86 / 64$ & $73 / 35$ & $55 / 76$ \\
\hline total & 95 & 161 & 226 & 110 & 150 & 108 & 131 \\
\hline $\begin{array}{l}\text { Urinary 17-OHCS } \\
\text { (mg/day) }\end{array}$ & $11.9-20.4$ & $16.9-25.7$ & $17.5-18.5$ & $14-21$ & $18.7-20.1$ & & $20.7-23.6$ \\
\hline $\begin{array}{l}\text { Urinary } 17-\mathrm{KS} \\
\text { (mg/day) }\end{array}$ & $23.6-37.4$ & $7.7-13.0$ & 5.2 & $13.0-14.5$ & $8.0-11.5$ & & $2.4-3.2$ \\
\hline $\begin{array}{l}\text { Plasma cortisol } \\
\qquad(\mu \mathrm{g} / \mathrm{dl})\end{array}$ & $13-20$ & $21-23$ & $27.5-32$ & $17-30$ & $17.0-31.9$ & $12-29$ & $19.5-26.9$ \\
\hline $\begin{array}{l}\text { Plasama ACTH }(\mathrm{pg} / \mathrm{ml}) \\
\text { before ADX } \\
\text { after ADX }\end{array}$ & & $\begin{array}{l}\text { low } \\
850\end{array}$ & $10-20$ & $\begin{array}{l}10 \\
19\end{array}$ & 10 & $14-20$ & 10 \\
\hline $\begin{array}{l}\text { Dexamethasone }(8 \mathrm{mg}) \\
\text { suppression }\end{array}$ & $(-)$ & $(-)$ & $(-)$ & $(-)$ & $(-)$ & $(-)$ & $(-)$ \\
\hline $\begin{array}{l}\text { Metyrapone } \\
\text { response }\end{array}$ & & $( \pm)$ & $(+)$ & $(-)$ & $(-)$ & $(+)$ & $(-)$ \\
\hline ACTH response & $(H)$ & $(+H)$ & $(+)$ & & $(H)$ & $(+)$ & $(+)$ \\
\hline $\begin{array}{l}\text { Insulin response } \\
\text { Plasma ACTH } \\
\text { Plasma cortisol }\end{array}$ & & & & & $\begin{array}{l}(-) \\
(+)\end{array}$ & & $\begin{array}{l}(-) \\
(+)\end{array}$ \\
\hline
\end{tabular}

ADX, bilateral adrenalectomy.

$(-)$, no response; $( \pm)$, low response; $(+)$, normal response; $(+)$, hyperresponse. 
1965; Katz, 1966; Neville \& Symington, 1967 ; Choi et al., 1970; Hartemann et al., 1971; Yamaoka, 1972; Burke \& Beardwell, 1973; Huguenin et al., 1973; Arce et al., 1978; Josse et al., 1980; Aron et al., 1981; Furukawa et al., 1981; Yamamoto et al., 1981 ; Miura et al., 1984) also indicated no suppression following the administration of $8 \mathrm{mg}$ of dexamethasone (20/23). However, more than half of the cases $(7 / 11)$ indicated responses to metyrapone, and most cases (17/22) showed a response to ACTH administration. Kirshner et al. (1964) first reported a patient with huge nodular adrenocortical hyperplasia whose adrenal glands weighed $94 \mathrm{~g}$, and since then several cases of huge nodular adrenocortical hyperplasia with adrenal weight over $90 \mathrm{~g}$ have been reported (Table 3). Most cases including our case showed low plasa ACTH levels $(5 / 5)$, no suppression to $8 \mathrm{mg}$ dexamethasone (6/6) and a hyperresponse to ACTH (6/7). An impaired response to metyrapone was found in 4 of 6 cases. Therefore, huge nodular adrenocortical hyperplasia has more adrenal autonomy than macronodular hyperplasia, although it shows a hyperresponse to ACTH.

Lamberts et al. (1984) suggested from in vitro experiments that adenomatous or macronodular adrenocortical hyperplasia with a lower ACTH level may sustain a longer hypercortisol state than diffuse adrenal hyperplasia. This may occur more markedly in huge nodular hyperplasia. Two cases $(2 / 2)$ with huge nodular hyperplasia including our case showed a cortisol response to insulin-induced hypoglycemia without an obvious plasma ACTH response. Our in vitro experiment showed that the nodular tissue had a cortisol response to ACTH but no response to other substances which might be elevated in peripheral blood by the insulin-induced hypoglycemia. There remains the possibility that cortisol might respond to other doses of these substances or to other agents which were not tested and the in vitro studies should have been performed at various glucose concentrations in an attempt to reproduce the in vivo conditions, since the response to insulin induced hypoglycemia involved not only the insulin level but also the developmet of hypoglycemia. For example the epinephrine in the concentration used or in higher concentrations could have caused an increase in cortisol secretion at a different level of glucose than the one used in the present study. Although it is difficult to draw a definite conclusion concerning cortisol responsiveness to insulin-induced hypoglycemia, it is possible that adrenal cortisol responded to a slight change in plasma ACTH which was not detected in the ACTH radioimmunoassay, as plasma ACTH levels lower than $10 \mathrm{pg} / \mathrm{ml}$ could not be detected with the ACTH radioimmunoassay (Hashimoto et al., 1985). ACTH receptors on hyperplastic adrenal cells might be up-regulated by low plasma ACTH levels.

The patient had high levels of urinary norepinephrine in conjunction with a positive MIBG uptake of the right adrenal medulla suggestive of right medullary hyperplasia, since a normal adrenal medulla does not image with MIBG. Unfortunately we did not confirm this histologically. After operation, urinary norepinephrine levels dropped to one third of the preoperative levels but were still a little high.

No conclusion can be drawn on the pathogenesis of huge nodular adrenocortical hyperplasia, although it appears likely that it may be a result of long standing macronodular adrenocortical hyperplasia. In summary, the results of this study of a huge nodular adrenocortical hyperplasia patient suggest that the characteristics of the disease are: low plasma ACTH level, no suppression with $8 \mathrm{mg}$ dexamethasone, an impaired or no response to metyrapone, a cortisol hyperresponse to ACTH and a cortisol response to insulin-induced hypoglycemia. 


\section{References}

Arce, B., M. Licea, S. Hung and R. Pardon (1978). Familial Cushing's syndrome. Acta Endocr. 87, 139-147.

Aron, D. C., J. W. Findling, P. A. Fitzgerand, R. M. Brooks, F. E. Fisher, P. H. Forsham and J. B. Tyrrell (1981). Pituitary ACTH dependency of nodular adrenal hyperplasia in Cushing's syndrome. Report of two cases and review of the literature. Am. J. Med. 71, 302306.

Burke, C. W. and C. G. Beardwell (1973). Cushing's syndrome: an evaluation of the clinical usefulness of urinary free cortisol and other urinary steroid measurements in diagnosis. $Q$. J. Med. 165, 175-204.

Choi, Y., E. E. Werk jr and L. J. Sholiton (1970). Cushing's syndrome with dual pituitary-adrenal control. Arch. Intern. Med. 125, 1045-1049.

Cohen, R. B. (1966). Observations on cortical nodules in human adrenal glands: their relationship to neoplasia. Cancer 19, 552-556.

Crapo, L. M. (1979). Cushing's syndrome. A review of diagnostic tests. Metabolism 28, 955-977.

Furukawa, K., K. Nakata, A. Kitazawa, J. Takamatsu, K. Fujita, T. Mozai, K. Matsumoto and K. Nakata (1981). An autopsy case of Cushing's syndrome due to pituitary adenoma and bilateral adrenocortical multinodular hyperplasia, associated with liver cirrhosis. Clinical Endocrinol. (Japanese) 29, 683-688.

Hartemann, P., J. Leclere, E. Mollet, N. de Talance, G. Grignon, F. Duminy and M. C. Cheval (1971). Syndrome de Cushing par hyperplasie surrenale bilaterale et adenome secretant unique. Discussion nosologique. Ann. Endocrinol. (Paris) 32, 788-800.

Hashimoto, K., R. Akiyama, Y. Kawada, S. Suemaru, T. Hattori and Z. Ota (1985). Measurement of plasma ACTH using an improved ACTH radioimmunoassay kit (C. I. S.). Clinical Endocrinol. (Japanese) 33, 807-812.

Hidai, H., H. Fujii, K. Otsuka, K. Abe and N. Shimizu (1975). Cushing's syndrome due to huge adrenocortical multinodular hyperplasia. Endocrinol. Japon. 22, 555-560.

Huguenin, A., B. Ferrand, D. Guerin, J. Kerisit and N. Murie (1973). Polymicroadenomatose de la cortico surrenale dans le syndrome de Cushing. Ann. Endocrinol. (Paris) 34, 206-215.
Ishihara, T., F. Uchihira, M. Tatsumi, T. Mori, T. Igarashi, H. Takayama and T. Ishikawa (1977). A case with Cushing's syndrome due to huge bilateral adrenal nodular hyperplasia. Folia Endocrinol. Jap. (Japanese) 53, 10821093.

Josse, R. G., R. Bear, K. Kovacs and H. P. Higgins (1980). Cushing's syndrome due to unilateral nodular hyperplasia: a new pathophysiological entity?. Acta Endocr. 93, 495504.

Katz, J. (1966). Failure of dexamethasone suppression in adrenal hyperplasia. Arch. Intern. Med. 118, 265-269.

Kirschner, M. A., R. D. Powell Jr and M. B. Lipsett (1964). Cushing's syndrome: nodular cortical hyperplasia of adrenal glands with clinical and pathological features suggesting adrenocortical tumor. J. Clin. Endocr. 24, 947955.

Krivitzky, A., P. Blondeau, J. P. Camilleri, G. Delzant and J. Roche-Sicot (1980). Syndrome de Cushing par adenome bilateral des surrenales. Ann. Med. Interne. (Paris) 131, 361364.

Lamberts, S. W., E. G. Bons and H. A. Bruining (1984). Different sensitivity to adrenocorticotropin of dispersed adrenocortical cells from patients with Cushing's disease with macronodular and diffuse adrenal hyperplasia. J. Clin. Endocrinol. Metab. 58, 1106-1110.

Matsukura, S., S. Sueoka, M. Yokota, Y. Hirata, B. Goto and T. Fujita (1982). A case of Cushing's syndrome with micronodular adrenal dysplasia. Clinical. Endocrinol. (Japanese). Vol. 30 Suppl. 198-201.

May, P. B., H. Sobel, G. Schneider and N. Ertel (1983). Nodular adrenal hyperplasia with elevated adrenocorticotropic hormone levels. Arch. Intern. Med. 143, 136-140.

Meador, C. K., B. Bowdoin, W. C. Owen and T. A. Farmer (1967). Primary adrenocortical nodular dysplasia: a rare cause of Cushing's syndrome. J. Clin. Endocrinol. Metab. 27, 12551263.

Mellinger, R. C. and R. W. Smith (1956). Studies of the adrenal hyperfunction in 2 patients with atypical Cushing's syndrome. J. Clin. Endocr. 16, 350-366.

Miura, M., Y. Matsukado, T. Kodama and R. Hiramatsu (1984). Adrenocortical nodular hyperplasia of the Cushing's disease -Diagnosis and surgical treatment-. No Shinkei Geka (Japanese) 12, 689-696. 
Mosier, H. D., P. J. Flynn, D. W. Will and R. D. Turner (1960). Cushing's syndrome with multinodular adrenal glands. J. Clin. Endocrinol. Metab. 20, 632-640.

Murayama, S., H. Tagawa, S. Tanaka and R. Takanashi (1983). A case with Cushing's syndrome due to huge nodular hyperplasia with dissecting aneurysm. Clinical Endocrinol. (Japanese). Vol. 31 Suppl. 141-143.

Neville, A. M. and A. M. Mackay (1976). The structure of human adrenal cortex in health and disease. Clin. Endocrinol. Metab. 1, 361395.

Neville, A. M. and T. Symington (1967). The pathology of the adrenal gland in Cushing's syndrome. J. Pathol. Bact. 93, 19-33.

Nishisato, K., N. Shima, Y. Tanahashi, A. Fukuzaki, N. Sasano, M. Ojima and T. Masuda (1979). Cushing's syndrome due to bilateral adrenocortical nodular hyperplasia. Igaku no Ayumi (Japanese) 109, 627-637.

Ruder, H. J., D. L. Loriaux and M. B. Lipsett (1974). Severe osteopenia young adults associated with Cushing's syndrome due to micronodular adrenal disease. J. Clin. Endocrinol. Metab. 39, 1138-1147.

Schteingart, D. E. and H. S. Tsao (1980). Coexistence of pituitary adrenocorticotropin-dependent Cushing's syndrome with a solitary adrenal adenoma. J. Clin. Endocrinol. Metab. 50, 961-
966.

Silverman, S. R., R. T. Marnell, L. J. Sholiton and E. E. Werk (1963). Failure of dexamethasone suppression test to indicate bilateral adrenocortical hyperplasia in Cushing's syndrome. J. Clin. Endocr. 23, 167-172.

Smals, A. G. H., G. F. F. M. Pieters, U. J. G. Van Haelst and P. W. C. Kloppenborg (1984). Macronodular adrenocortical hyperplasia in long-standing Cushing's disease. 58, 25-31.

Takai, M., K. Kaneko, K. Takaki, A. Shibata, K. Kano, H. Sekiguchi, J. Abe and T. Nishikawa (1983). A case of Cushing's syndrome with primary adrenocortical nodular dysplasia with neoplastic disease in various endocrine glands. Clinical Endocrinol. (Japanese) Vol. 31 Suppl. 138-140.

Tucci, J. R., C. R. Meloni, G. G. Carreon and J. J. Canary (1965). Pituitary-adrenal functional abnormalities in corticogenic adrenal atrophy. J. Clin. Endocr. 25, 823-831.

Yamamoto, T., N. Aoki and M. Enomoto (1981). A case of Cushing's syndrome with bilateral nodular adrenal hyperplasia. Metabolism and Disease (Japanese) 18, 387-394.

Yamaoka, T. (1972). Clinical and pathological investigations on Cushing's syndrome. A view on the classification of the syndrome. Jpn. J. Surgery 73, 287-296. 